\title{
Aplikasi Kaolin dalam Farmasi dan Kosmetik
}

\section{Kaolin Application in Pharmaceuticals and Cosmetics}

\author{
Hayatus Sa'adah*, Marline Abdassah, Anis Yohana Chaerunisaa \\ Departemen Farmasetika dan Teknologi Farmasi, \\ Fakultas Farmasi, Universitas Padjadjaran \\ Jl. Raya Bandung-Sumedang Km. 21 Jatinangor 45363, Sumedang, Indonesia \\ *Corresponding author email: hayatussa@gmail.com
}

Received 3-11-2019 Accepted 4-12-2019 Available online 30-12-2019

\begin{abstract}
ABSTRAK
Kaolin merupakan mineral tanah liat berwarna putih yang memiliki komponen terbesar berupa kaolinit dengan rumus kimia $\mathrm{Al}_{2} \mathrm{O}_{3} \cdot 2 \mathrm{SiO}_{2} \cdot 2 \mathrm{H}_{2} \mathrm{O}$. Penggunaan kaolin untuk pengobatan berawal dari literatur-literatur barat abad pertengahan, terutama setelah kemunculan pendekatan yang lebih empiris terhadap efek farmakologi, pembentukan farmakope, perkembangan mineralogi, kimia dan teknologi farmasi, kemajuan dalam teknik instrumental, dan peningkatan dari reputasi terapeutik mineral. Kaolin dengan persyaratan khusus dapat digunakan dalam aplikasi farmasi (topikal maupun oral) dan kosmetik. Kaolin telah banyak digunakan sebagai obat dalam penyembuhan tradisional selama ribuan tahun dan penggunaannya sebagai bahan aktif untuk pengobatan beberapa penyakit terus diteliti. Artikel terkait pengumpulan informasi penggunaan kaolin dalam aplikasi farmasi dan kosmetik belum banyak dilakukan, sehingga artikel ini dibuat untuk mengulas peran dan fungsi kaolin dalam aplikasi farmasi dan kosmetik. Tujuan keseluruhan dari artikel ini adalah untuk memberikan informasi tentang pemanfaatan dan pengembangan kaolin sebagai bahan aktif atau eksipien dalam bidang farmasi dan kosmetik. Kaolin dapat diberikan secara oral sebagai antibakteri, antivirus, dan antidiare, dan secara topikal sebagai agen pelindung dermatologis. Selain sebagai bahan aktif, kaolin juga biasa digunakan dalam aplikasi farmasi sebagai bahan eksipien. Beberapa fungsi dari kaolin sebagai eksipien yaitu sebagai bahan pengisi, agen pengemulsi, agen suspensi, dan bahan penghancur. Selain dalam aplikasi farmasi, kaolin juga digunakan dalam aplikasi kosmetik sebagai agen tabir surya dan untuk tujuan perawatan kulit. Metode penulisan artikel ini ditulis berdasarkan studi literatur dari artikel dan jurnal yang relevan dengan permasalahan yang dikaji.
\end{abstract}

Kata kunci: bahan aktif farmasi, eksipien, kaolin, kosmetik. 


\begin{abstract}
Kaolin is a white clay mineral whose largest component in the form of kaolinite with the chemical formula of $\mathrm{Al}_{2} \mathrm{O}_{3} \cdot 2 \mathrm{SiO}_{2} \cdot 2 \mathrm{H}_{2} \mathrm{O}$. The use of kaolin for the medicinal purposes originated in medieval western literature, especially after the emergence of a more empirical approach to the effects of pharmacology, pharmacopoeial formation, mineralogy development, pharmaceutical chemistry and technology, advances in instrumental techniques, and improvements in mineral therapeutic reputation. Kaolin, with special requirements, can be used in pharmaceutical applications (topical or oral) and cosmetics. Kaolin has been widely used as a medicine in traditional healing systems for thousands of years and its use as an active ingredient for the treatment of several diseases continues to be investigated. Articles related to the information on the use of kaolin in pharmaceutical and cosmetic applications are not available much, hence this article was written to review the role and function of kaolin in pharmaceutical and cosmetic applications. The overall purpose of this article is to provide information about the use and development of kaolin as an active ingredient or excipient in the pharmaceutical and cosmetic fields. The method of writing this article is based on the study of literature from articles and journals that are relevant to the problem under study. Kaolin can be administered orally as an antibacterial, antiviral, and antidiarrheal, and topically as a dermatological protective agent. Apart from being an active ingredient, kaolin is also commonly used in pharmaceutical applications as excipient ingredients. As excipients, some functions of kaolin are fillers, emulsifying agents, suspension agents, and disintegrant agents. In addition to pharmaceutical applications, kaolin is also used in cosmetic applications as a sunscreen agent and for skincare purposes.
\end{abstract}

Key words: active pharmaceutical ingredients, cosmetics, excipients, kaolin.

\section{Pendahuluan}

Tanah liat merupakan bahan baku yang umum digunakan dalam aplikasi kesehatan dan kosmetik setelah banyaknya para peneliti yang mempelajari dan melaporkan bagaimana sifat fisik dan kimianya (Mattioli et al., 2016; Roselli et al., 2015; Silvavalenzuela et al., 2018). Kriteria untuk memilih bahan baku tanah liat untuk aplikasi teknologi tertentu, tergantung pada sifat dan tingkat kemurnian tanah liat tersebut, seperti komposisi mineral, distribusi ukuran partikel, reaktivitas dan aktivitas katalitik, luas permukaan spesifik, kapasitas pengembangan dan kapasitas pertukaran kation. Untuk aplikasi di bidang kesehatan, kriteria tanah liat yang bisa digunakan dapat dilihat dari bagaimana prinsip aktif, kemampuan adsorben, dan kemampuan sebagai eksipien (Silva-valenzuela et al., 2018).

Dalam formulasi farmasi dan kosmetik, persyaratan lain juga harus dipenuhi untuk menghindari potensi risiko terhadap kesehatan manusia. Dalam kasus ini, stabilitas, inert terhadap reaksi kimia, toksisitas rendah atau nol, dan aktivitas mikrobiologis harus sesuai 
dengan batas yang direkomendasikan dalam Standar Farmakope Indonesia maupun Internasional, bahkan dari segi fisik, warna yang menyenangkan, bau netral, kelembutan, dan sifat reologinya juga harus disesuaikan (Silva-valenzuela et al., 2018).

Mineral tanah liat telah digunakan oleh industri farmasi dan kosmetik untuk beberapa penggunaan seperti eksipien, karena sifat reologisnya, atau sebagai zat dengan aktivitas biologis, karena sifat kimianya. Industri kosmetik, telah banyak menggunakan mineral tanah liat karena memiliki karakteristik yang menarik seperti mudah dalam aplikasi dan mudah dibersihkan, meminimalisir waktu pengeringan, dan tidak berbahaya secara dermatologis (Velasco et al., 2016).

Kaolin merupakan salah satu mineral tanah liat yang digunakan pada sebagian besar aplikasi industri. Kaolin harus memiliki distribusi ukuran partikel yang sangat halus (kurang dari $2 \mu \mathrm{m}$ ) dan berkualitas tinggi terutama untuk aplikasi seperti plastik, cat, industri kertas, farmasi, dan kosmetik. Kaolin murni $\left(\mathrm{Al}_{2} \mathrm{O}_{3} .2 \mathrm{SiO}_{2} .2 \mathrm{H}_{2} \mathrm{O}\right)$ memiliki warna putih (Abdel-Khalek et al., 2014). Kaolin dapat terbebas dari pengotor ( $\mathrm{FeO}$, $\mathrm{CaCO}_{3}, \mathrm{MgCO}_{3}$ ) dengan elutriasi dan pengeringan. Pengotor yang terdapat pada kaolin bergantung pada tempat asal yang akan mempengaruhi tingkat gangguan dan ukuran partikel (Aleanizy et al., 2014).

\section{Aplikasi Kaolin dalam Farmasi sebagai Bahan Aktif dan Eksipien}

Kaolin telah banyak digunakan sebagai obat dalam penyembuhan tradisional selama ribuan tahun dan penggunaannya sebagai bahan aktif untuk pengobatan beberapa penyakit terus diteliti. Kaolin dapat diberikan secara oral sebagai antibakteri, antivirus, dan antidiare, dan secara topikal sebagai agen pelindung dermatologis. Selain sebagai bahan aktif, kaolin juga biasa digunakan dalam aplikasi farmasi sebagai bahan eksipien.

Bahan eksipien yang digunakan harus bersifat inert dan dapat memfasilitasi proses desain formulasi obat. Penggunaan eksipien dalam proses desain formulasi obat sangat dibutuhkan untuk meningkatkan penampilan, menjaga stabilitas dan konsistensi bentuk sediaan akhir. Selain itu, penggunaan eksipien juga dapat memperbaiki sifat farmakokinetik obat seperti meningkatkan ketersediaan hayati dan mengontrol pelepasan komponen aktif dalam pemberian dan penghantaran obat.

Kaolin dalam aplikasi farmasi telah banyak digunakan sebagai eksipien dalam formulasi bentuk sediaan padat dan semi-padat, termasuk tablet, kapsul, pil, granul, serbuk, pasta, tapal, salep, krim, lotion, dan suspensi. Konsentrasi kaolin untuk tujuan tertentu telah ditentukan dari beberapa formularium obat. Beberapa fungsi dari kaolin sebagai eksipien yaitu sebagai pengisi, agen pengemulsi, agen suspensi, dan 
penghancur (Rowe et al., 2009; Dogan et al., 2012).

\section{Antibakteri}

Kaolin (kaolinit) telah dilaporkan memiliki aktivitas sebagai antibakteri (Otto dan Haydel, 2013). Lafi dan AlDulaimy (2011) melaporkan bahwa gray clay (kaolin) memiliki aktivitas bakterisidal terhadap bakteri Staphylococcus aureus. Aktivitas antibakteri dari kaolin ini dikaitkan dengan sifat fisik dan/atau kimianya. Proses bakterisidal fisik terjadi karena adanya adsorpsi permukaan antara partikel kaolin dan dinding sel bakteri karena tarikan elektrostatiknya. Bakteri Pseudomonas putida dan Staphylococcus gallinarum menunjukkan afinitas adsorpsi yang tinggi terhadap permukaan kaolin (kaolinit) (Lafi dan AlDulaimy, 2011). Daya tarik permukaan ini menyebabkan pembungkusan sel-sel bakteri dan mengganggu penyerapan nutrisi metabolik mereka (Vasiliadou et al., 2011; Abdel-Khalek et al., 2014).

\section{Komposit ZnO/kaolinit} dilaporkan memiliki aktivitas antibakteri terhadap S. aureus, Escherichia coli, Enterococcus faecalis, dan Pseudomonas aeruginosa. Potensi ini disebabkan oleh aktivitas fotokatalitik komposit ZnO/kaolinit dan interaksi biologisnya dengan sel bakteri (Dedkova et al., 2015). Kaolin (kaolinit) yang dimodifikasi dengan dimetil sulfoksida (DMSO) menjadi nanokomposit, berdasarkan tes antimikroba terhadap strain bakteri $S$. aureus, E. coli dan terhadap ragi Candida albicans dilaporkan memiliki efisiensi antimikroba yang sangat baik (Holesova et al., 2016). Jou and Malek (2016) telah mempelajari aktivitas perak-kaolinit (CAAg-kaol) yang mengandung klorheksidin asetat sebagai agen antibakteri. Berdasarkan hasil penelitian, dilaporkan perak-kaolinit yang mengandung klorheksidin asetat dapat digunakan sebagai agen antibakteri yang efektif karena aktivitas antibakterinya yang tinggi terhadap bakteri spektrum luas (Jou dan Malek, 2016).

Antivirus

Ali et al. (2014) melakukan penelitian untuk mengevaluasi aktivitas anti-HCV (hepatitis C virus) dari mineral kaolin. Hasilnya, turunan mineral kaolin menunjukkan efek penghambatan yang menjanjikan terhadap infeksi genotipe 3a dan 1a HCV, yang menunjukkan kemungkinan penggunaannya sebagai obat komplementer dan alternatif untuk infeksi virus HCV (Ali et al., 2014).

Hasil penelitian Bellou et al. (2015) menunjukkan bahwa adenovirus patogen enterik manusia (hAdVs) dan coliphage (MS2 dan ФX174) dapat dihilangkan dengan adsorpsi pada permukaan kaolin (kaolinit) yang dibuat larutan encer (Bellou et al., 2015). Silva et al. (2015) menunjukkan bahwa partikel kaolinit yang tersuspensi dalam air mengurangi jumlah salinan genom virus dan infektivitas adenovirus 5 (HAdV-5) (Silva et al., 2015).

\section{Antidiare}

Primandini et al. (2012) melakukan penelitian terhadap peningkatan adsorpsi kaolin dengan kalsinasi (suhu $400{ }^{\circ} \mathrm{C}$ ), hasil penelitian didapat bahwa kaolin yang dilakukan 
kalsinasi lebih efektif sebagai antidiare dibanding kaolin tanpa dikalsinasi (Primandini et al., 2012). Kaolin merupakan senyawa mineral yang tidak larut dalam air, asam mineral, dan larutan alkali hidroksida.

Kaolin adalah salah satu adsorben usus utama. Kaolin secara tradisional telah digunakan secara internal dalam pengobatan berbagai gangguan enterik, kolitis, enteritis, disentri, dan diare yang berhubungan dengan makanan dan keracunan alkaloid (Aleanizy et al., 2014). Kemampuan antidiare dari kaolin dikaitkan dengan hidrofilisitas, luas permukaan, mikroporositas, osmotik air dan sifat retensi kaolin (kaolinit), serta efek antibakteri dan antivirusnya (Wardhana et al., 2014).

\section{Pelindung Dermatologis}

Kaolinit telah digunakan secara topikal sebagai agen tabir surya aktif untuk menipiskan efek radiasi ultraviolet matahari (UV-B dan UV-A, masingmasing rentang panjang gelombang spektral 290-320 nm dan 320-400 nm) yang bertanggung jawab atas kerusakan kulit dan kanker. terutama dengan kaolinit yang memiliki kandungan $\mathrm{Fe}_{2} \mathrm{O}_{3}$ yang tinggi (Etich et al., 2014).

Masker wajah, krim, tapal dan lotion yang mengandung kaolinit menunjukkan aktivitas terapi sebagai perawatan antiacne, karena ini menyerap lipid permukaan, sekresi berminyak dan sel kulit mati yang terkelupas, serta menyerap racun superfisial (misalnya, racun pohon ek dan poison ivy), bakteri dan virus yang dapat menyebabkan infeksi jerawat, dan oleh karena itu, mencegah cacat, komedo dan mengurangi penyebaran jerawat (Pura et al., 2014). Marcotegui et al. (2015) melaporkan aplikasi kaolin untuk meredakan dan menyembuhkan bekas gigitan serangga (Marcotegui et al., 2015).

\section{Kaolin sebagai Bahan Pengisi}

Pilihan bahan pengisi yang tepat pada dasarnya tergantung pada hidrofobisitas dan bioavailabilitas komponen aktif. Pengisi yang larut dalam air direkomendasikan dalam formulasi dengan bahan aktif yang kelarutannya rendah dalam air, dan sebaliknya. Pemilihan bahan eksipien tersebut bertujuan untuk menghindari masalah ketersediaan hayati (bioavailabilitas). Tes fisik dan parameter yang paling penting yang direkomendasikan untuk memenuhi syarat kaolin sebagai pengisi dalam bentuk sediaan padat meliputi kerapatan serbuk, kehalusan serbuk, kelembaban, kekerasan, kerapuhan, waktu hancur, disolusi atau profil pelepasan obat (Mathur et al., 2015; Uddin et al., 2015). Kaolin yang diformulasikan harus kompatibel dengan komponen aktif dan eksipien lain yang terlibat. Eksipien yang memiliki sifat adsorben tinggi tidak dapat diterima pada batas kritis untuk formulasi tablet atau kapsul. Bahan aktif yang dikonsumsi secara klinis dalam dosis kecil (misalnya glikosida jantung, alkaloid, dan estrogen sintetik) tidak dapat ditambahkan eksipien dengan sifat adsorben tinggi. Penambahan eksipien tersebut dapat menyebabkan bahan 
aktif diserap dalam jumlah yang tinggi, dan menurunkan bioavailabilitas setelah pemberian (Shalini, 2012).

Banyak penelitian farmasi telah dicoba untuk menentukan peran kaolin, sebagai pengisi atau peran sebagai eksipien lainnya, untuk menyerap dan melepaskan molekul bahan aktif. Interaksi obat dan kaolin dapat terjadi, seperti mengurangi pelepasan molekul obat aktif yang dapat dipengaruhi oleh adsorpsi yang kuat. Kaolin dengan sifat adsorpsi yang kuat dapat digunakan sebagai eksipien dalam formulasi obat sistem pelepasan terkendali. Dalam hal dosis obat rendah, kaolin dapat ditambahkan sebagai pengisi hingga $90 \%$ atau lebih ke dalam bahan aktif tablet atau kapsul untuk menambah volume, memfasilitasi kompresi dan/atau menambah berat dan ukuran bentuk sediaan padat sesuai yang ditentukan.

Onyishi et al. (2013) menunjukkan bahwa kapsul pyridoxine hydrochloride (vitamin B6) yang diformulasikan dengan kaolin sebagai pengisi berhasil dibuat untuk sistem penghantaran obat lepas terkendali (Onyishi et al., 2013). Aleanizy et al. (2015) mempelajari interaksi antara kaolin dan metronidazole (antibiotik dan obat antiprotozoa) dan menyimpulkan bahwa adsorpsi isoterm Langmuir dari obat bergantung pada $\mathrm{pH}$ kaolin dan dikontrol oleh konsentrasi kaolin. Selain itu, pemberian tablet kaolinmetronidazole (Riazole ${ }^{\circ}$ ) secara bersamaan mempengaruhi pelepasan dan difusi metronidazole (Aleanizy et al., 2014). Hu et al. (2015) menunjukkan adsorpsi fisik eksotermis antara permukaan kaolin dan atenolol (obat $\beta$ blocker) yang berkurang dengan meningkatkan kekuatan ionik larutan obat. Hubungan cincin $\mathrm{NH},-\mathrm{O}-$, dan benzena adalah ligan pengkelat utama yang bertanggung jawab atas interaksi ini (Hu et al., 2015). Yu dan Bi (2015) mempelajari penyerapan naproxen (obat antiinflamasi asam) ke permukaan kaolin. Mereka mengaitkan adsorpsi kuat ini dengan interaksi antara cincin diaromatik obat dan permukaan siloxane kaolinit (Yu dan Bi, 2015).

Secara keseluruhan, kaolin dapat dianggap sebagai eksipien yang terjangkau, dengan perhatian khusus pada interaksi dengan bahan farmasi aktif. Interaksi kaolin dengan obatobatan dapat berguna dalam desain sistem penghantaran obat yang dimodifikasi (Viseras et al., 2010).

Kaolin sebagai Agen Pengemulsi

Formulasi emulsi memerlukan penambahan agen pengemulsi, untuk menstabilkan ketidakmampuan bercampur fase minyak dan fase air sebagai emulsi minyak dalam air atau air dalam minyak. Mekanisme emulsifikasi digambarkan dengan penurunan tegangan antarmuka antara dua fase tak bercampur atau gaya tolak yang mempertahankan kedua fase tersuspensi dalam media dispersi. Emulsifikasi juga tergantung pada sudut kontak tiga fase (minyak-air-padatan) (Bora et al., 2014).

Kpogbemabou et al. (2014) mempelajari kemampuan kaolin untuk menstabilkan emulsi pickering minyak 
dalam air, di mana dodekana $\left(\mathrm{C}_{12} \mathrm{H}_{26}\right)$ adalah fase minyak yang digunakan dalam formulasi. Hasil menunjukkan bahwa kaolin (15\%) ditambahkan ke fase berair (pada $\mathrm{pH}=7,2$ ) memperlihatkan stabilitas emulsi jangka panjang tanpa adanya surfaktan. Tawfeek et al. (2014) meneliti efek kaolinit pada stabilisasi emulsi minyak-dalam-minyak yang tidak berair. Peneliti ini menemukan bahwa kaolinit yang dicampur dengan minyak parafin/formamida tidak memberikan sistem emulsi yang stabil pada semua konsentrasi, sementara penambahan surfaktan nonionik noigen RN10 (polyoxyethylene alkylphenyl ether) meningkatkan stabilitas emulsi. Surfaktan ini meningkatkan keterbasahan partikel kaolinit, karenanya stabilitas emulsi ini meningkat (Tawfeek et al., 2014). Jadi, dalam formulasi semi-padat topikal, permukaan kaolinit dapat diaktifkan untuk bertindak sebagai agen ampifilik untuk meningkatkan dan menstabilkan ketidakmampuan air dari obat hidrofobik agar berada dalam fase homogen terdispersi.

Kaolin sebagai Agen Pensuspensi

Suspensi kasar adalah sistem dispersi yang memiliki fase dispersi dengan ukuran partikel lebih besar dari 1 $\mu \mathrm{m}$, sedangkan sol koloid menunjukkan diameter partikel kurang dari $1 \mu \mathrm{m}$. Agen pensuspensi dan anticaking adalah bahan eksipien yang digunakan untuk menstabilkan keadaan deflokulasi partikel tersuspensi agar mudah disebarkan kembali ketika mengocok wadah obat dengan lembut sebelum digunakan. Agen pensuspensi juga dapat mempertahankan homogenitas sistem dan mencegah penguraian komponen padat di bagian bawah wadah. Stabilitas suspensi disebabkan oleh efek energi potensial elektrostatik dari tolakan yang timbul di antara partikel bermuatan (potensial zeta) dari eksipien. Untuk kinerja yang baik, agen pensuspensi harus menunjukkan sifat yield stress dan viskositas tinggi ketika shear rates rendah, tahan terhadap beragam suhu, stabil sepanjang penyimpanan jangka panjang, menghasilkan konsentrasi elektrolit yang signifikan, dan juga harus bertindak secara konsisten pada rentang pH yang luas (Kulshreshtha et al., 2010).

Suspensi kaolin (kaolinit) terutama ditandai oleh perilaku aliran pseudoplastik (penipisan geser) nonNewtonian dengan Bingham yield stress, di mana viskositas menurun dengan meningkatnya shear rates. Perubahan karakteristik reologi dan stabilitas larutan suspensi kaolin disebabkan oleh perbedaan muatan permukaan partikel (zeta potensial), yang dipengaruhi oleh variasi dalam kristalinitas kaolin, konsentrasi elektrolit, dan nilai $\mathrm{pH}$. Secara umum, yield stress dan tingkat pengendapan larutan suspensi kaolin menurun dengan meningkatnya $\mathrm{pH}$ dan zeta potensial (Gupta et al., 2011). Larutan suspensi yang diformulasikan dengan kaolin kristalinitas rendah menunjukkan tekanan dan viskositas lebih tinggi daripada yang diformulasikan dengan kaolin kristalinitas tinggi (Ndlovu et al., 2015). 
Muatan negatif yang dominan pada permukaan kaolin terhidrasi kaolinit menyebabkan terjadinya tolakan elektrostatik di antara partikel. Oleh karena itu, partikel cenderung distabilkan jika terjadi deflokulasi. Dengan demikian, kaolinit sering digunakan sebagai agen pensuspensi dalam formulasi farmasi.

Kaolin sebagai Bahan Penghancur

Penghancur adalah komponen eksipien yang digunakan untuk memfasilitasi fragmentasi atau memecah bentuk sediaan padat menjadi partikulat ketika kontak dengan cairan saluran pencernaan setelah pemberian sehingga memudahkan pelepasan dan penyerapan bahan aktif (Gopinath et al., 2012). Goyanes et al. (2013) mengevaluasi co-precipitate chitosan/kaolin sebagai penghancur dalam formulasi pelet mikrokristalin selulosa dan hidroclorotiazid (HCT). Hasilnya menunjukkan bahwa pelet ini hancur sempurna dengan cepat dalam media disolusi, tidak secara signifikan mempengaruhi pelepasan HCT, tetapi meningkatkan laju disolusi obat (Goyanes et al., 2013).

Singkatnya, kaolin (kaolinit) sebagai bahan berpori dan mudah gembur dengan pengembangan yang rendah oleh hidrasi, dapat dianggap sebagai peghancur yang baik dalam bentuk sediaan padat. Porositas membantu dalam penetrasi air yang membantu penguraian partikel besar menjadi fragmen yang lebih kecil. Selain itu, permukaan terhidrasi dari partikel kaolin yang didominasi oleh muatan negatif bertanggung jawab untuk meningkatkan daya hancur karena tolakan elektrostatik.

\section{Aplikasi Kaolin dalam Kosmetik}

Bahan anorganik banyak digunakan dalam kosmetik, digunakan bersama dengan bahan organik untuk membuat kosmetik sebaik mungkin. Bahan anorganik dapat digunakan sebagai bahan pengisi, bahan pengadsorpsi, menstabilkan busa, alas bedak, dan concealer untuk menutupi ketidaksempurnaan dan memberikan tampilan kulit alami. Kaolin (kaolinit) adalah salah satu bahan anorganik yang banyak digunakan dalam industri kosmetik (Hameed et al., 2019).

Kaolin sebagai Agen Tabir Surya (sunscreen)

Radiasi ultraviolet adalah masalah nyata bagi kesehatan manusia dan dikatakan menyebabkan kanker kulit dan penyakit kulit lainnya. Penyakitpenyakit ini merupakan beban ekonomi dalam hal diagnosis, perawatan, dan pencegahan di negara-negara berkembang. Tabir surya dari sumbersumber alami seperti tanaman dan tanah liat saat ini sedang dieksplorasi sebagai agen tabir surya yang murah, dapat diandalkan, banyak tersedia dan dapat menjadi alternatif yang sederhana untuk kesehatan kulit (Etich et al., 2014).

Penggunaan tanah liat dalam aplikasi kosmetik telah banyak dipelajari (Dlova et al., 2013). Etich et al. (2014) memaparkan bahwa tanah liat yang banyak digunakan sebagai pelindung kulit salah satunya adalah mineral kaolin 
(kaolinit). Ini dapat terjadi karena kemampuan adsorbennya dan mampu menempel pada kulit membentuk film, yang melindunginya secara mekanis terhadap agen fisik dan kimia (Etich et al., 2014).

Kaolin sebagai Agen Perawatan Kulit (Skin Care)

Kesehatan kulit adalah aspek penting dari estetika. Dermatologis dan ilmuwan mencoba mengembangkan metode dan bahan baru untuk memenuhi tujuan ini. Kosmetik wajah menjaga kelembapan kulit dan menghilangkan sebum dari kulit untuk menjaga kesehatan kulit. Penggunaan kosmetik yang cocok sesuai dengan jenis kulit wajah menghasilkan kulit yang sehat (Nilforoushzadeh et al., 2018).

Masker wajah adalah produk kosmetik yang paling umum digunakan untuk peremajaan kulit (Nilforoushzadeh et al., 2018). Velasco et al. (2016) memaparkan penggunaan kaolin sebagai masker wajah. Kaolin yang dicampur dengan air dapat diaplikasikan langsung pada kulit pada suhu kamar. Untuk mengobati masalah kulit seperti komedo, flek hitam, dan jerawat, disarankan kaolin diaplikasikan menggunakan air panas. Suhu panas dapat meningkatkan sekresi keringat dan sebaceous, juga membuka lubang pilosebaceous dan mengaktifkan perubahan metabolisme dan ekskresi katabolit (Velasco et al., 2016).

"Kulit mengkilap" mengacu pada penampilan kulit wajah yang berminyak, sering kali paling menonjol di dahi, dan dagu, yang dihasilkan oleh akumulasi sebum pada permukaan kulit. Kulit mengkilap menyusahkan banyak orang dengan jerawat sebagai bagian dari masalah yang ditimbulkan karena memiliki "kulit berminyak". Masalah tersebut dapat dikurangi untuk sementara waktu sampai taraf tertentu dengan pengaplikasian zat yang tidak mengiritasi yang menyerap sebum. Kaolin merupakan salah satu bahan yang dapat menyerap sebum biasanya dimasukkan ke dalam produk kosmetik yang dipromosikan untuk mengurangi kulit berminyak (Rosso, 2013).

\section{Simpulan}

Kaolin merupakan salah satu mineral yang memiliki banyak manfaat dan penggunaan dalam berbagai aplikasi diberbagai bidang. Dalam bidang farmasi, kaolin dapat digunakan sebagai bahan aktif farmasi maupun eksipien. Selain itu, kaolin juga digunakan dalam bidang kosmetik untuk tujuan perawatan kulit.

\section{Daftar Pustaka}

Abdel-Khalek, N.A., Selim, K.A., Mohammed, S.E., El-Hendawy, H.H., Elbaz, R.M. 2014. Interaction between kaolinite and Staphylococcus gallinarum Bacteria. Journal of Mining World Express, 3:46-52.

Aleanizy, F.S., Alqahtani, F., Al-Gohary, O., El-Tahir, E., Al-Shalabi, R. 2014. Determination and characterization of metronidazole-kaolin interaction. Saudi Pharmaceutical Journal, 
23(2):167-176.

Ali, L., Idrees, M., Ali, M., Hussain, A., Rehman, I.U., Ali, A., Kamel, E.H. 2014. Inhibitory effect of kaolin minerals compound against hepatitis $c$ virus in Huh-7 cell lines. BMC Research Notes, 247(7):1-5.

Bellou, M.I., Syngouna, V.I., Tselepi, M.A., Kokkinos, P.A., Paparrodopoulos, S.C., Vantarakis, A., Chrysikopoulos, C.V. 2015. Interaction of human adenoviruses and coliphages with kaolinite and bentonite. Science of the Total Environment, 517:86-95.

Bora, A., Deshmukh, S., Swain, K. 2014. Recent advantages in semisolid dosage form. International Journal of Pharmaceutical Sciences and Research, 5(9): 3594-3608.

Dedkova, K., Janikova, B., Matejova, K., Peikertova, P., Neuwirthova, L., Holesinsky, J., Kukutschova, J. 2015. Preparation, characterization and antibacterial properties of ZnO/kaoline nanocomposites. Journal of Photochemistry \& Photobiology, 148:113-117.

Dlova, N.C., Nevondo, F.T., Mwangi, E.M., Summers, B., TsokaGwegweni, J., Martincigh, B.S., Mulholland, D.A. 2013. Chemical analysis and in vitro uvprotection characteristics of clays traditionally used for sun protection in South Africa. Photodermatology, Photoimmunology
Photomedicine, 26:164-169.

Dogan, M., Dogan, A.U., Aburub, A., Botha, A., Wurster, D.E. 2012. Quantitative mineralogical properties (morphologychemistry-structure) of pharmaceutical grade kaolinites and recommendations to regulatory agencies. Microscopy and Microanalysis, 18(1):143151.

Etich, W.K.N., Mwangi, E.M., Kiptoo, J., Digo, C.A., Ombito, J.O. 2014. In vitro determination of sun protection factor on clays used for cosmetic purposes in Kenya. Chemistry and Materials Research, 6(7):25-31.

Gopinath, H., Shanmugasundaram, S., Kumar, P. 2012. A brief review on disintegrants. Journal of Chemical and Pharmaceutical Sciences, 5(3):105-112.

Goyanes, A., Souto, C., Martinezpacheco, R. 2013. Chitosankaolin coprecipitate as disintegrant in microcrystalline cellulose-based pellets elaborated by extrusionspheronization. Pharmaceutical Development and Technology, 18(1):137-145.

Gupta, V., Hampton, M.A., Stokes, J.R., Nguyen, A.V., Miller, J.D. 2011. Particle interactions in kaolinite suspensions and corresponding aggregate structures. Journal of Colloid and Interface Science, 359(1):95-103.

Hameed, A., Fatima, G.R., Malik, K., Muqadas, A., Rehman, M.F. 
2019. Scope of nanotechnology in cosmetics: dermatology and skin care products. Journal of Medicinal and Chemical Sciences, (2):9-16.

Holesova, S., Hundakova, M., Pazdziora, E. 2016. Antibacterial kaolinite based nanocomposites. Procedia Materials Science, 12:124-129.

Hu, Y., Fitzgerald, N.M., Lv, G., Xing, X., Jiang, W., Li, Z. 2015. Adsorption of atenolol on kaolinite. Advances in Materials Science and Engineering, 2015: Article ID 897870 .

Jou, S.K., and Malek, N.A.N.N. 2016. Characterization and antibacterial activity of chlorhexidine loaded silverkaolinite. Applied Clay Science, 127-128:1-9.

Kulshreshtha, A.K., Singh, O.N., Wall, G.M. 2010. Pharmaceutical Suspensions: from Formulation Development to Manufacturing. New York: Springer.

Lafi, S.A. and Al-Dulaimy, M.R. 2011. Antibacterial effect of some mineral clays. Egyptian Academic Journal of Biological Sciences, 3(1):75-81.

Marcotegui, A., Sanchez-Ramos, I., Pascual, S., Fernandez, C.E., Cobos, G., Armendariz, I., Gonzalez-Nunez, M. 2015. Kaolin and potassium soap with thyme essential oil to control Monosteira unicostata and other Phytophagous arthropods of almond trees in organic orchards. Journal of Pest Science,
88(4):753-765.

Mathur, N., Kumar, R., Tiwari, K., Singh, S., Fatima, N. 2015. Evaluation of quality control parameters on various brands of paracetamol tablet formulation. World Journal of Pharmacy and Pharmaceutical Sciences, 4(07):976-984.

Mattioli, M., Giardini, L., Roselli, C., Desideri, D. 2016. Mineralogical characterization of commercial clays used in cosmetics and possible risk for health. Applied Clay Science, 119(2):449-454.

Ndlovu, B., Farrokhpay, S., Forbes, E., Bradshaw, D. 2015. Characterisation of kaolinite colloidal and flow behaviour via crystallinity measurements. Powder Technology, 269:505512.

Nilforoushzadeh, M.A., Amirkhani, M.A., Zarrintaj, P., Moghaddam, A.S., Mehrabi, T., Alavi, S., Sisakht, M.M. 2018. Skin care and rejuvenation by cosmeceutical facial mask. Journal Cosmetic Dermatology, 17(5):693-702.

Onyishi, V.I., Chime, S.A., Adibe, C.V. 2013. Formulation of pyridoxine hydrochloride sustained release capsules: effect of propylene glycol co-solvent on the in vitro release. African Journal of Pharmacy and Pharmacology, 7(15):809-815.

Otto, C.C. dan Haydel, S.E. 2013. Microbicidal clays : composition, activity, mechanism of action, and therapeutic applications. In 
Microbial Pathogens and Strategies for Combating them: Science, Technology And Education. A. Méndez-Vilas, A. (Ed). Badajoz, Spain: Formatex Research Center.

Primandini, P., Hasanah, A.N., A, W. A., Budianto, E., and Sudirman. 2012. Pengaruh suhu kalsinasi terhadap kemampuan adsorpsi toksin pada kaolin untuk peyakit diare. Jurnal Sains Materi Indonesia, 13(3):230-235.

Pura, A., Dusenkova, I., Malers, J. 2014. Adsorption of organic compounds found in human sebum on latvian illitic, kaolinitic, and chloritic phyllosilicates agnese. Clays and Clay Minerals, 62(6):500-507.

Roselli, C., Desideri, D., Cantaluppi, C., Mattioli, M., Fasson, A. 2015. Essential and toxic elements in clays for pharmaceutical and cosmetic use. Journal of Toxicology and Environmental Health, 78(5):316-324.

Rosso, J.Q.D. 2013. The role of skin care as an integral component in the management of Acne vulgaris part 1: the importance of cleanser and moisturizer. Journal Clinical Aesthet Dermatology, 6(12):19-27.

Rowe, R.C., Sheskey, P.J., Quinn, M.E. 2009. Handbook of Pharmaceutical Excipients (Sixth). USA: Pharmaceutical Press.

Silva-valenzuela, M. das G., Chambiperalta, M.M., Sayeg, I.J.,
Carvalho, F.M. de S., Wang, S.H., and Valenzuela-díaz, F.R. 2018. Enrichment of clay from vitoria da conquista (Brazil) for applications in cosmetics. Applied Clay Science, 155:111119.

Silva, H.D., Pessoa-de-souza, M.A., Fongaro, G., Anunciacao, C.E., Silveira-lacerda, E.D.P., Barardi, C.R.M., Garcia-zapata, M.T.A. 2015. Behaviour and recovery of human adenovirus from tropical sediment under simulated conditions. Science of the Total Environment, 530-531:314-322.

Tawfeek, A.M., Dyab, A.K.F., Al-Lohedan, H.A. 2014. Synergetic effect of reactive surfactants and clay particles on stabilization of nonaqueous oil-in-oil (O/O) emulsions. Journal of Dispersion Science and Technology, 35(2):265-272.

Uddin, S., Al-Mamun, A., Tasnu, T., Asaduzzaman. 2015. In-process and finished products quality control tests for pharmaceutical tablets according to pharmacopoeias. Journal of Chemical and Pharmaceutical Research, 7(9):180-185.

Vasiliadou, I.A., Papoulis, D., Chrysikopoulos, C.V, Panagiotaras, D., Karakosta, E., Fardis, M., Papavassiliou, G. 2011. Attachment of Pseudomonas putida onto differently structured kaolinite minerals : a combined ATR-FTIR and $1 \mathrm{H}$ NMR study. Colloids and Surfaces B: Biointerfaces, 84(2):354-359. 
Velasco, M.V.R., Zague, V., Dario, M.F., Nishikawa, D.O., Pinto, C.A.S.O., Almeida, M.M., Baby, A.R. 2016. Characterization and short-term clinical study of clay facial mask. Journal of Basic and Applied Pharmaceutical Sciences, 37(1): 1-6.

Viseras, C., Cerezo, P., Sanchez, R., Salcedo, I., Aguzzi, C. 2010. Current challenges in clay minerals for drug delivery. Applied Clay Science, 48(3):291295.
Wardhana, Y.W., Hasanah, A.N., Primandini, P. 2014. Deformation and adsorption capacity of kaolin that is influenced by temperature variation on calcination. International Journal of Pharmacy and Pharmaceutical Science, 6(3):1-2.

Yu, C. dan Bi, E. 2015. Roles of functional groups of naproxen in its sorption to kaolinite. Chemosphere, 138:335-339. 